\title{
Evaluation of the Decay Constant of Uranium 235 from Lead Isotope Ratios ${ }^{1}$
}

\author{
Phimip O. Banks \\ Department of Geology, Western Reserve University, Cleveland, Ohio \\ LeON T. SILVER \\ Division of Geological Sciences, California Institute of Technology \\ Pasadena
}

\begin{abstract}
The decay constant of $U^{* 35}$ has been evaluated from the radiogenic $\mathrm{Pb}^{207} / \mathrm{Pb}^{2011}$ ratios of several cogenetic fractions of zircon and uranothorite, analyzed by conventional mass spectrometric methods. Variation of the $\mathrm{Pb}^{208} / \mathrm{U}^{m 9}$ apparent ages among the mineral fractions demonstrates that some form of isotopic disturbance has occurred during their geologic history. Arguments are presented to show that the method of calculating $\lambda_{3 a s}$ is relatively insensitive to such disturbance because of the young geologic age of the samples and the probability that zircon and uranothorite experience isotopic disturbance by partial loss of $\mathrm{Pb}$. Inaccuracy in the calculated value is further reduced by deducing, from geologic and isotopic considerations, the most likely limits to the apparent ages to which the $\mathrm{Pb}^{207} / \mathrm{Pb}^{206}$ ratios should correspond. Although the uncertainties in the method do not permit a unique derivation of the decay constant, the results suggest that the currently accepted value is probably accurate to within $1 \%$, relative to the accepted values for the decay constant of $U^{\text {ss }}$ and the isotopic composition of natural $\mathrm{U}$.
\end{abstract}

Currently accepted values for the decay constants and abundance ratio of the naturally occurring unsupported $\mathrm{U}$ isotopes are:

$$
\begin{gathered}
\lambda_{238}=1.537 \times 10^{-10} \mathrm{yr}^{-1} \pm 0.2 \% \\
{[\text { Fleming et al., 1952] }} \\
\lambda_{235}=9.72 \times 10^{-10} \mathrm{yr}^{-1} \pm 2.2 \% \\
{[\text { Fleming et al., 1952] }} \\
\mathrm{U}^{238} / \mathrm{U}^{235}=137.96 \pm 0.1 \%
\end{gathered}
$$$$
\text { [Greene et al, 1955] }
$$

The relatively large uncertainty in the value of $\lambda_{\operatorname{mas}}$ compared with the other constants has vccasionally been suggested as contributing to small discrepancies between geologic age determinations made by the U-Pb and other methods. For this reason, as well as intrinsic interest, we have examined isotopic data from a suite of U-bearing mineral samples to investigate whether the accepted value of $\lambda_{\text {sas }}$ might actually be as much in error as suggested by the assigned uncertainty.

\footnotetext{
${ }^{1}$ Contribution 1404, Division of Geological Sciences, California Institute of Technology.
}

Ideally, changes in the concentrations of $\mathrm{Pb}$ and $U$ in a U-bearing mineral would take place only by radioactive decay. If such closed-system conditions exist, the age $T$ of the mineral sample can be obtained from the ratio of radiogenic $\mathrm{Pb}^{206}$ to $\mathrm{U}^{23 s}$ according to the equation

$$
T=\left(1 / \lambda_{238}\right) \ln \left[\mathrm{Pb}^{206} / \mathrm{U}^{23 s}+1\right]
$$

$\lambda_{\text {axs }}$ can then be calculated from the ratio of radiogenic $\mathrm{Pb}^{207}$ to radiogenic $\mathrm{Pb}^{\mathrm{mov}}$ by means of the equation

$\lambda_{233}=\frac{1}{T} \ln \left[k\left(\frac{\mathrm{Pb}^{207}}{\mathrm{~Pb}^{208}}\right)\left(e^{\lambda_{23 \mathrm{~s} T} T}-1\right)+1\right]$

where $k$ is the abundance ratio of the uranium isotopes.

Alternatively, it is possible to calculate $\lambda_{235}$ from the ratio of radiogenic $\mathrm{Pb}^{30 \mathrm{~T}}$ and $\mathrm{U}^{\mathrm{wes}}$ (where $\mathrm{U}^{\text {was }}=\mathrm{U}^{23 s} / k$ ):

$$
\lambda_{235}=T^{-1} \ln \left[\mathrm{Pb}^{207} / \mathrm{U}^{235}+1\right]
$$

Equation 2, however, has the advantage that errors in measuring the concentrations of $\mathrm{Pb}$ and $U$ have a smaller effect on the calculated value. 
Of course, neither equation 2 nor 3 provides a truly independent determination of $\lambda_{n a 5}$, for any errors in the accepted values of $\lambda_{2 a s}$ or $k$ will appear in the result. Yet the uncertainties assigned to these constants and the errors in conventional mass spectrometry are small enough so that if minerals were closed systems it would be possible to calculate $\lambda_{235}$ with a precision considerably better than $2 \%$.

Nier $[1939 a, b]$ employed a variation of the methods outlined above with remarkable success in his pioneering applications of modern methods of mass spectrometry. However, subsequent work has shown that natural U-Pb systems seldom behave according to the closedsystem model. Commonly the concentration of $\mathrm{Pb}$ or $\mathrm{U}$ is changed by processes other than radioactive decay, resulting in a variable uncertainty in the calculation of $\lambda_{235}$ which depends on the geologic age of the sample and the mechanism and degree of isotopic disturbance. This phenomenon is discussed more fully below because the need to minimize the associated uncertainty has governed our choice of samples. Its widespread occurrence in Ubearing minerals has led later workers to rely on independent methods of determining $\lambda_{m 35}$ Fleming et al. [1952] obtained the presently accepted value by measuring the specific activity of artificially enriched $\mathrm{U}^{\mathrm{mas}}$. Their assigned uncertainty of $2.2 \%$ was derived after a thorough and conservative consideration of the sources of error, the largest of which was due to the presence of $U^{2 s}$ in the enriched material. A more precise independent determination will require more efficiently enriched $\mathrm{U}^{235}$ and/or improved counting techniques.

Isotopic disturbances of a mineral sample during its geologic history may take place in a number of ways; gain or loss of $\mathrm{U}$, gain or loss of $\mathrm{Pb}$, or gain or loss of intermediate daughter products. Such gains or losses could occur more or less continuously, as by concentration-dependent diffusion, or episodically, as by a short interval of heating or leaching. It is not within the scope of this paper to discuss in detail the possible results of this variety of mechanisms. Some aspects have been discussed by Wetherill [1956a, b, 1963], Russell and Ahrens [1957], Tilton [1960], and Wasserburg [1963]. Briefly, the mechanisms can be distinguished by their differential effects on the apparent ages calculated from the ratios $\mathrm{Pb}^{20}$, $\mathrm{U}^{209}, \mathrm{~Pb}^{207} / \mathrm{U}^{235}, \mathrm{~Pb}^{507} / \mathrm{Pb}^{200}$ and the way in which these apparent ages depart from the true age of the mineral.

The true age, though, is seldom known a priori. To investigate the mechanisms of disturbance in real samples, the following operational method may be employed. A suite of mineral samples is obtained from a single rock specimen, so that the entire suite has the same true age and has undergone an identical history. To ensure that the mechanism of disturbance is probably the same for all samples, all members of the suite should consist of the same mineral species, but each should differ from the others in the degree of disturbance that has been experienced (one possible way of accomplishing this is by separating the members on the basis of $\mathrm{U}$ content). Each member is isotopically: analyzed and the results are plotted on a concordia diagram $\left(\mathrm{Pb}^{200} / \mathrm{U}^{203}\right.$ versus $\mathrm{Pb}^{207} / \mathrm{U}^{\infty 8}$ [Wetherill, 1956a]). The pattern of analytical points on the diagram will serve to limit the possible mechanisms of disturbance, although it will not usually provide a unique interpretation. Further discussion of the use of cogenetic samples may be found in Silver [1963] and Silver and Deutsch [1963].

We are especially familiar with a large body of data obtained from analyses of cogenetic fractions of the mineral zircon, in which $U$ occurs as a trace constituent. Samples of widely varying age, $U$ content, and degree of disturbance are represented. In all these data we have never seen any that could not be interpreted in terms of simple partial loss of $\mathrm{Pb}$, either by episodic removal or by some combination of concentration-dependent diffusion and episodic loss. This interpretation is based on the observation that the analytical data for each cogenetic suite of zircons, plotted on the concordia diagram, form a linear array lying on the concave side of the concordia curve. By using zireon analyses in calculating $\lambda_{235}$, and accepting the general validity of our observation that $\mathrm{Pb}$ loss is the dominant mechanism of disturbance in zircon, it is possible to deduce an important limitation to the direction of uncertainty caused by isotopic disturbance. Partial loss of $\mathrm{Pb}$ yields the following characteristics (see, for example, Wetherill [1956a] for a discussion of the effects of episodic $\mathrm{Pb}$ loss) : 


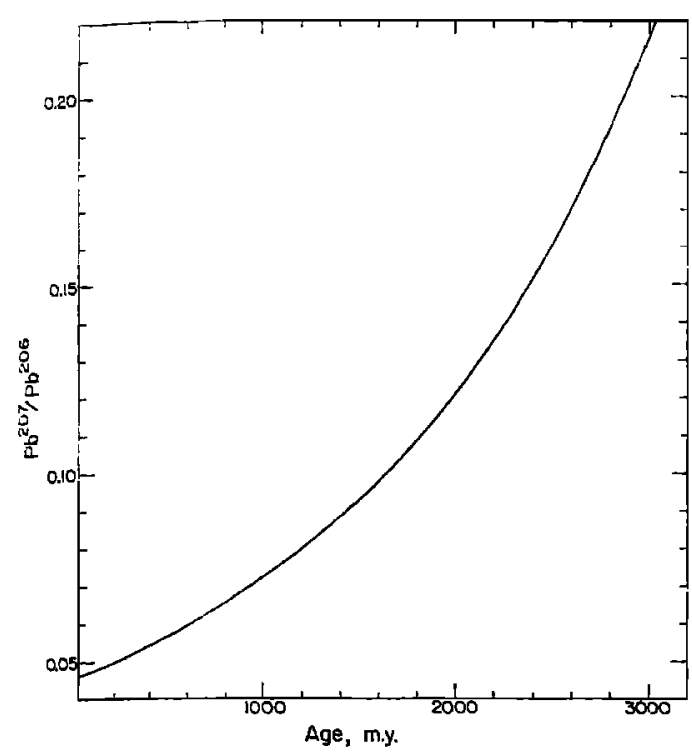

Fig. 1. Relationship between true age and the radiogenic $\mathrm{Pb}^{207} / \mathrm{Pb}^{200}$ ratio for ideally closed minerals. The smaller slope at younger ages makes the exact age in this region less critical for calculating $\lambda_{\text {as }}$.

1. The apparent age calculated from the $\mathrm{Pb}^{200} / \mathrm{\tau}^{-938}$ ratio is always less than the true age.

2. The radiogenic $\mathrm{Pb}^{507} / \mathrm{Pb}^{200}$ ratio must correspond to an apparent age somewhere between the $\mathrm{Pb}^{208} / \mathrm{U}^{2 a s}$ apparent age and the true age.

These relationships imply that the direct application of equations 1 and 2 to an analysis of a zircon sample in which $\mathrm{Pb}$ loss has occurred will result in a value of $\lambda_{2 s 5}$ that is, in general, too large, because the $\mathrm{Pb}^{000} / \mathrm{U}^{\text {ratio }}$ corresponds to an apparent age usually lower, but never higher, than the apparent age to which the $\mathrm{Pb}^{207} / \mathrm{Pb}^{200}$ ratio corresponds.

The magnitude of the error introduced by ealculating $\lambda_{235}$ without regard to the possible occurrence of $\mathrm{Pb}$ loss cannot be shown in any simple way. The observed isotope ratios for a given sample are a reflection of the correct values of $\lambda_{20 s}$ and $\lambda_{2 s 5}$, the true age of the sample, the amount of isotopic disturbance, and the precise way in which the disturbance has occurred. We assume that $\lambda_{2 s s}$ is accurately known. It is possible to eliminate, in a general way at least, the uncertainty of how isotopic disturbance has occurred by using cogenetic suites of samples. Only one of the remaining variables is independent; for example, if the true age is known, the amount of Pb loss, and hence $\lambda_{25 s}$, can be calculated. Unfortunately, none of these variables is known a priori. This is equivalent to saying that there is a family of concordia curves, each curve corresponding to one of the possible values of $\lambda_{255}$. A given cogenetic suite defines a unique line of discordance. The upper (older) intersection of this line with each member of the family of concordia curves specifies a particular combination of values for $\lambda_{\mathrm{sss}}$ and true age which would produce the observed isotope ratios by an appropriate amount of $\mathrm{Pb}$ loss.

For very old minerals the problem has no solution. However, as the true age of the sample decreases, the uncertainty created by a given degree of isotopic disturbance has a diminishing effect on the calculation of $\lambda_{2 s s}$ because the radiogenic $\mathrm{Pb}^{507} / \mathrm{Pb}^{200}$ ratio is a more slowly varying function of age for younger ages than for older ages. Figure 1 shows how the $\mathrm{Pb}$ isotope ratio changes with age in an ideally closed mineral. In the limiting case of a mineral with zero true age, $\lambda_{255}$ could be calculated accurately from its $\mathrm{Pb}$ isotope composition regardless of any amount or mechanism of partial $\mathrm{Pb}$ loss, provided that such a mincral could be analyzed.

To illustrate how the magnitude of uncertainty in the calculated value of $\lambda_{2 a s}$ is related both to the degree of disturbance and to the true age, it is necessary to assume a particular process of disturbance. We assume that the mineral is isotopically disturbed by losing a portion of its $\mathrm{Pb}$ episodically at a very recent time. Analyses of a cogenetic suite of samples so disturbed, when plotted on the concordia diagram, will define a straight line which passes through the origin. In this simple case, the $\mathrm{Pb}^{207} / \mathrm{Pb}^{208}$ ratio of each member of the suite will correspond to the true age $(T)$ of the suite because there has been no modification of the radiogenic lead by further decay after the disturbance. The $\mathrm{Pb}^{200} / \mathrm{C}^{20 s}$ ratio, however, will correspond to an apparent age which is less than the true age by an amount commensurate with the amount of $\mathrm{Pb}$ lost. Direct application of equation 1 will yield this apparent age, which is here called the assigned age $\left(T^{\prime}\right)$ of the mineral. By substituting the assigned age into equation 2 we obtain a value 


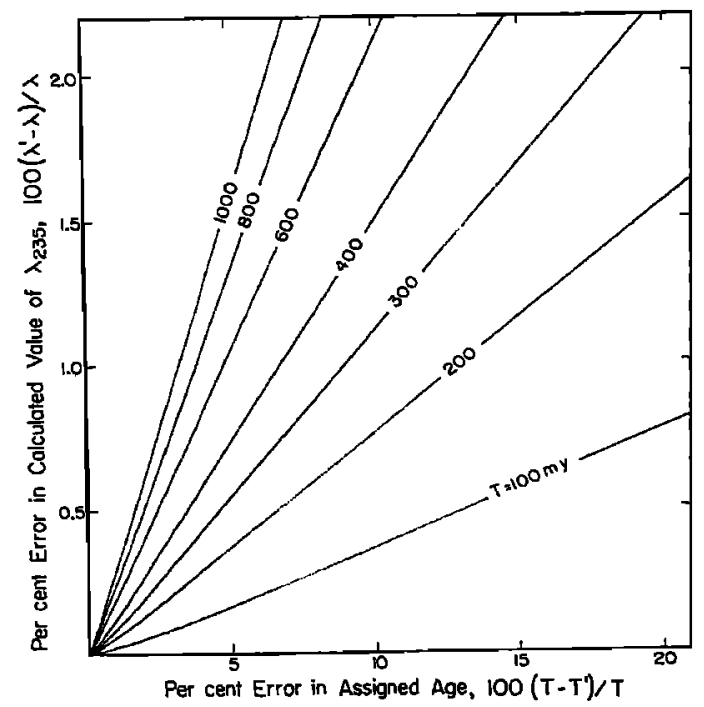

Fig. 2. Per cent error in the value of $\lambda_{035}$ calculated from the $\mathrm{Pb}^{207} / \mathrm{Pb}^{208}$ ratio, shown as a function of the error in the assigned age, for the model discussed in the text. Curves are drawn for various values of the true age $(T)$. The assigned age $\left(T^{\prime}\right)$ is equivalent to the $\mathrm{Pb}^{\text {aco }} / \mathrm{U}^{\text {2as }}$ apparent age of the sample. It is assumed that the $\mathrm{Pb}^{207} / \mathrm{Pb}^{=00}$ ratio should correspond to the true age, which would be the case if a fraction of the lead was episodically removed from the sample at a recent time.

of $\lambda_{295}$ that is larger than the correct value by an amount related both to the true age and to the degree of disturbance. Figure 2 shows the error in $\lambda_{2 a s}$ as a function of the error in the assigned age for this model. Each curve corresponds to a particular value of the true age. Suppose we wish to determine $\lambda_{2 a s}$ to $1 \%$ (exclusive of analytical error). It is readily seen from Figure 2 that an increasingly large degree of disturbance can be tolerated as the age of the sample decreases. A sample with a true age of $100 \mathrm{~m} . \mathrm{y}$, for example, may be $20 \%$ disturbed, yet the calculation of $\lambda_{235}$ will be in error by less than 1\%. Although this model is not strictly applicable to most real systems, which apparently lose $\mathrm{Pb}$ either by continuous diffusion or by episodic loss at some intermediate time in their history, the general conclusion remains valid that the calculation of $\lambda_{205}$ becomes less sensitive to errors in the assigned age as the true age decreases.

To summarize the foregoing consideration, a reasonably precise evaluation of $\lambda_{2 x 5}$ can be made from mineral samples if a mechanism of disturbance can be postulated which has a known effect on the isotope ratios and if the samples have a sufficiently young true age. To meet the first criterion we have chosen, as previously described, the mineral zircon, which appears to undergo isotopic disturbance by loss of $\mathrm{Pb}$. A few supplementary analyses of the isomorphous mineral uranothorite have also been included. The few data at our disposal on the behavior of uranothorite suggest that it experiences a similar isotopic disturbance to that of zircon. This particular choice of minerals places a practical lower limit of about $100 \mathrm{~m} . \mathrm{y}$. on the geologic age of useful samples because zircon seldom contains a sufficiently high content of $U$ to have generated an adequate amount of $\mathrm{Pb}$ for analysis during a period significantly less than 100 m.y.

The desired conditions were fulfilled by twelve fractions of zircon and four fractions of uranothorite taken from six samples of the coarse- and fine-grained phases of the Mount Rubidoux leucogranite, Riverside County, California [Larsen, 1948]. Geologic evidence indicates that the two phases of granite were emplaced at very nearly the same time; therefore the mineral fractions constitute a cogenetic suite. The following factors render these samples particularly favorable:

1. The Rubidoux granites are part of the Cretaceous batholith of southern California. Their true age is approximately $120 \mathrm{~m} . \mathrm{y}$, and, as explained previously, the decay-constant calculation is thus relatively insensitive to small uncertainties in the true age.

2. The $\mathrm{Pb}^{200} / \mathrm{U}^{209}$ apparent age of each zircon fraction is a function of its $U$ content. It can therefore be recognized that the samples are isotopically disturbed, and a correction can be estimated for this condition which further reduces the error in the calculated value of $\lambda_{305}$.

3. The $\mathrm{Pb}$ in most samples is markedly radiogenic. In addition, a wide range of $\mathrm{Pb}^{ \pm 0}$ / $\mathrm{Pb}^{\mathrm{su}}$ values was observed, permitting the derivation of composite radiogenic $\mathrm{Pb}^{207} / \mathrm{Pb}^{200}$ ratios without the necessity of a specific common $\mathrm{Pb}$ correction.

Sample numbers are as follows: SCB-36 and SCB-107 are specimens of fresh coarse granite 
TABLE 1. Calibration and Comparison of Mass Spectrometer Operating Characteristics

\begin{tabular}{|c|c|c|c|c|c|c|c|c|c|}
\hline Experiment & $\begin{array}{c}\text { Mass } \\
\text { Spectrometer }\end{array}$ & Collector System & $\begin{array}{c}\begin{array}{c}\text { Obs } \\
\mathrm{Pb}^{200}\end{array} \\
\mathrm{~Pb}^{204}\end{array}$ & $\frac{\mathrm{Pb}^{206}}{\mathrm{~Pb}^{207}}$ & $\frac{\mathrm{Pb}^{206}}{\mathrm{~Pb}^{208}}$ & $\begin{array}{l}\text { Gorr. } \mathrm{fc} \\
\frac{\mathrm{Pb}^{906}}{\mathrm{~Pb}^{204}}\end{array}$ & $\begin{array}{c}\text { or Discrin } \\
\sqrt{M I} \\
\mathrm{~Pb}^{206}\end{array}$ & $\begin{array}{l}\text { mination, } \\
\frac{\mathrm{Pb}^{206}}{\mathrm{~Pb}}\end{array}$ & $\begin{array}{c}\text { No. } \\
\text { of Data } \\
\text { Sets }\end{array}$ \\
\hline $\begin{array}{l}\text { A gravimetrically pre- } \\
\text { pared mixture of } \\
\text { nearly pure } \mathrm{Pb}^{200} \\
\text { and } \mathrm{Pb}^{208} \text { isotope }\end{array}$ & $\begin{array}{l}\text { CIT MIS-12-1 } \\
\text { (used in this } \\
\text { work) }\end{array}$ & Electron multiplier & , & & 1.0123 & & & 1.0074 & 19 \\
\hline $\begin{array}{l}\text { end members. Atom } \\
\text { ratio from gravime- } \\
\text { try }=1.0089 \pm \\
0.002 \text {. } \\
\text { (All data taken } \\
\text { from a single load } \\
\text { on one filament.) }\end{array}$ & CIT MS-12-2 & $\begin{array}{l}\text { Electron multiplier } \\
\text { Faraday cup }\end{array}$ & & & $\begin{array}{l}1.0101 \\
1.0037\end{array}$ & & & 1.0053 & 29 \\
\hline $\begin{array}{l}\text { radiogenic lead ex- } \\
\text { tracted from a zir- } \\
\text { con and loaded on a } \\
\text { single filament for } \\
\text { both runs. }\end{array}$ & $\begin{array}{l}\text { CIT MS-12-1 } \\
\text { CIT MS-12-2 }\end{array}$ & $\begin{array}{l}\text { Electron multiplier } \\
\text { Faraday cup }\end{array}$ & $\begin{array}{l}1670 . \\
1670 .\end{array}$ & $\begin{array}{l}9.100 \\
9.072\end{array}$ & $\begin{array}{l}6.988 \\
6.939\end{array}$ & 1678 & 9078 & 6.954 & $\begin{array}{l}17 \\
15\end{array}$ \\
\hline $\begin{array}{l}\text { CIT shelf standard } \\
\text { lead. Individual } \\
\text { loads and runs. }\end{array}$ & $\begin{array}{l}\text { CIT MIS-12-1 } \\
\text { CIT MS-12-2 } \\
\text { NBS-4* }\end{array}$ & $\begin{array}{l}\text { Electron multiplier } \\
\text { Faraday cup } \\
\text { Faraday cup }\end{array}$ & $\begin{array}{l}16.658 \\
16.640 \\
16651\end{array}$ & $\begin{array}{l}1.0768 \\
1.0733 \\
1.0733\end{array}$ & $\begin{array}{l}0.4588 \\
0.4567 \\
0.4568\end{array}$ & 16.670 & I 0741 & 0.04564 & $\begin{array}{l}18 \\
15\end{array}$ \\
\hline
\end{tabular}

* Doe et al. [1965], average of six runs.

from two different localities. SCB-101C $s$ is a are, respectively, fresh and weathered samples specimen of weathered ( $\mathrm{C}$ zone) coarse gran- of the fine granite. Mineral separates from each ite. SCB-108 is a sample of weathered rind sample were split into two size fractions: taken from the same residual weathering $-100+200$ mesh (R200) and -200 mesh boulder as SCB-107. SCB-102 and SCB-106 (P200). The zircon fractions were washed for

TABLE 2. Analytical Results for Zircon Fractions from the

Coarse- and Fine-Grained Mount Rubidoux Granites

(Sample numbers are explained in the text.)

\begin{tabular}{|c|c|c|c|c|c|c|c|}
\hline $\begin{array}{c}\text { Sample } \\
\text { No. }\end{array}$ & $\begin{array}{c}\text { Size } \\
\text { Fraction }\end{array}$ & $\begin{array}{l}\text { Weight, } \\
\text { mg }\end{array}$ & $\begin{array}{l}\text { U Concen- } \\
\text { tration, } \\
\text { ppm }\end{array}$ & $\begin{array}{c}\mathrm{Pb}^{208} / \mathrm{Pb}^{204} \\
\text { Observed }\end{array}$ & $\begin{array}{c}\mathrm{Pb}^{206} / \mathrm{Pb}^{207} \\
\text { Observed }\end{array}$ & $\begin{array}{l}\mathrm{Pb}^{206} / \mathrm{U}^{398} \\
\text { Apparent } \\
\text { Age, m.y. }\end{array}$ & $\begin{array}{l}\mathrm{Pb}^{207} / \mathrm{Pb}^{206} \\
\text { Radiogenic }\end{array}$ \\
\hline \multirow[t]{2}{*}{ SCB-36 } & $\mathrm{R} 200$ & 383 & 1882 & 1786 & 17.69 & 114 & 0.04831 \\
\hline & $\mathrm{P} 200$ & 733 & 2307 & 1414 & 17.05 & 113 & 0.04825 \\
\hline \multirow{2}{*}{ SCB-107 } & $\mathrm{R} 200$ & 452 & 1765 & 1826 & 17.74 & 110 & 0.04832 \\
\hline & $\mathrm{P} 200$ & 489 & 2370 & 1105 & 16.25 & 110 & 0.04826 \\
\hline \multirow[t]{2}{*}{ SCB-101C 3} & $\mathrm{R} 200$ & 454 & 1937 & 1367 & 16.72 & 105 & 0.04907 \\
\hline & $\mathrm{P} 200$ & 452 & 2415 & 1653 & 17.49 & 103 & 0.04828 \\
\hline \multirow{2}{*}{ SCB-108 } & $\mathrm{R} 200$ & 502 & 1771 & 1711 & 17.52 & 108 & 0.04850 \\
\hline & P200 & 463 & 2253 & 2036 & 17.85 & 107 & 0.04881 \\
\hline \multirow[t]{2}{*}{ SCB-102 } & R200 & 351 & 2639 & 335 & 11.19 & 110 & 0.04783 \\
\hline & P200 & 572 & 3000 & 892 & 15.40 & 108 & 0.04849 \\
\hline \multirow[t]{3}{*}{ SCB-106 } & $\mathrm{R} 200$ & 426 & 2676 & 1194 & 16.22 & 108 & 0.04937 \\
\hline & P200 & 295 & 2990 & 1230 & 16.39 & 108 & 0.04908 \\
\hline & lomm & $\mathbf{r}$ & & $\begin{array}{c}\mathrm{Pb}^{206} / \mathrm{Pb}^{204} \\
17.83\end{array}$ & $\begin{array}{c}\mathrm{Pb}^{307} / \mathrm{Pb}^{204} \\
15.55\end{array}$ & $\begin{array}{c}\mathrm{Pb}^{208} / \mathrm{Pb}^{204} \\
37.62\end{array}$ & \\
\hline
\end{tabular}


TABLE 3. Analytical Results for Uranothorite Fractions from the Coarse-Grained Mount Rubidoux Granite

\begin{tabular}{|c|c|c|c|c|c|c|c|}
\hline $\begin{array}{c}\text { Sample } \\
\text { No. }\end{array}$ & Description & $\begin{array}{c}\text { Weight, } \\
\text { mg }\end{array}$ & $\begin{array}{c}\text { U Concen- } \\
\text { tration, } \\
\%\end{array}$ & $\begin{array}{c}\mathrm{Pb}^{206} / \mathrm{Pb}^{204} \\
\text { Observed }\end{array}$ & $\begin{array}{c}\mathrm{Pb}^{206} / \mathrm{Pb}^{207} \\
\text { Observed }\end{array}$ & $\begin{array}{l}\mathrm{Pb}^{206} / \mathrm{U}^{238} \\
\text { Apparent } \\
\text { Age, m.y. }\end{array}$ & $\begin{array}{l}\mathrm{Pb}^{207} / \mathrm{Pb}^{26} \\
\text { Radiogenic }\end{array}$ \\
\hline \multirow[t]{5}{*}{ SCB-36 } & \multirow{4}{*}{$\begin{array}{l}\text { Composite R200 } \\
\text { Composite P200 } \\
\text { Hand-picked } \\
\text { R200A } \\
\text { Hand-picked } \\
\text { R200B }\end{array}$} & $\begin{array}{l}8.3 \\
3.8\end{array}$ & $\begin{array}{l}8.16 \\
8.10\end{array}$ & $\begin{array}{l}1634 \\
1037\end{array}$ & $\begin{array}{l}17.54 \\
15.95\end{array}$ & $\begin{array}{l}97 \\
97\end{array}$ & $\begin{array}{l}0.04801 \\
0.04852\end{array}$ \\
\hline & & & & & & & \\
\hline & & 4.1 & 10.81 & 629 & 14.02 & 87 & 0.04797 \\
\hline & & 5.7 & 9.82 & 498 & 12.65 & 111 & 0.04962 \\
\hline & \multicolumn{3}{|c|}{ Common lead correction } & $\begin{array}{c}\mathrm{Pb}^{206} / \mathrm{Pb}^{204} \\
17.83\end{array}$ & $\begin{array}{c}\mathrm{Pb}^{207} / \mathrm{Pb}^{204} \\
15.55\end{array}$ & $\begin{array}{c}\mathrm{Pb}^{208} / \mathrm{Pb}^{204} \\
37.62\end{array}$ & \\
\hline
\end{tabular}

at least 1 hour in hot concentrated $\mathrm{HNO}_{3}$ before analysis, whereas the uranothorite fractions were untreated beforehand. Concentrations of $\mathrm{U}$ and $\mathrm{Pb}$ were measured by isotope dilution.

Data were obtained on a 12 -inch, $60^{\circ}$ sector, single-focusing mass spectrometer equipped with an electron multiplier, a 50\% transmission grid, and a dual-pen strip chart recorder. The over-all reproducibility characteristics of this instrument (CIT MS-12-1) have been discussed by Chow and McKinney [1958]. McKinney [1961] rechecked the calibration of the recorder shunt resistances and has investigated discrimination in the electron multiplier. His results indicate that in the Tl-U region the discrimination closely approximates the theoretical square root of the mass value. The required corrections for mass discrimination and recorder shunts are of the order of a few tenths of $1 \%$, except that in most cases the low intensity of the $\mathrm{Pb}^{\mathrm{sis}}$ peak necessitated a $2 \%$ shunt correction for the $\mathrm{Pb}^{208} / \mathrm{Pb}^{204}$ ratio.

Isotope ratios were measured in sets by scanning once up-mass and once down-mass and averaging the peak heights for each such set. The following table illustrates the average character of the individual $\mathrm{Pb}$ composition runs:
One of us (L.T.S.) has made a detailed study of the calibration and operating characteristics of CIT mass spectrometers for $\mathrm{Pb}$ isotope analysis. Initial results are shown for comparison in Table 1. This work will be presented in more detail elsewhere.

Analytical results for the twelve zircon fractions are shown in Table 2, and for the uranothorites in Table 3. The variation of $\mathrm{Pb}^{208} / \mathrm{J}^{\mathrm{m}}$ apparent ages among the analyses indicates the existence of isotopic disturbance in these minerals. The apparent ages of the zircon fractions from each rock sample are a function of U content, as illustrated in Figure 3. Also shown in Figure 3 are four repeat concentration analyses of SCB-36 R200 and an analysis of one fraction of $\mathrm{SCB}^{-101 \mathrm{C}_{3}}$ for which the $\mathrm{Pb}$ composition was not obtained. The composition of the SCB$101 C_{a}$ P200 fraction was assumed to apply to this sample. On the basis of the repeat analyses of SCB-36 R200, $\mathrm{Pb} / \mathrm{U}$ concentration ratios by isotope dilution appear to have an average reproducibility of about $1 \%$; thus the spread in apparent ages is well outside analytical uncertainty.

It is not possible to demonstrate directly that the isotopic disturbance of these samples is compatible with simple loss of $\mathrm{Pb}$ because the decay of $U$ during a $100-m . y$. interval is almost

\begin{tabular}{lccccc}
\cline { 5 - 6 } & \multicolumn{2}{c}{$\mathrm{Pb}^{200 / \mathrm{Pb}^{204}}$} & & \multicolumn{2}{c}{$\mathrm{Pb}^{206} / \mathrm{Pb}^{207}$} \\
\cline { 2 - 3 } \cline { 5 - 6 } & No. of & Avg. Deviation & & No. of & Avg. Deviation \\
Zircons & Sets & from Mean, \% & & Sets & from Mean, \% \\
Uranothorites & 12 & 1.9 & & 15 & 0.32 \\
& 7 & 1.0 & & 16 & 0.26
\end{tabular}




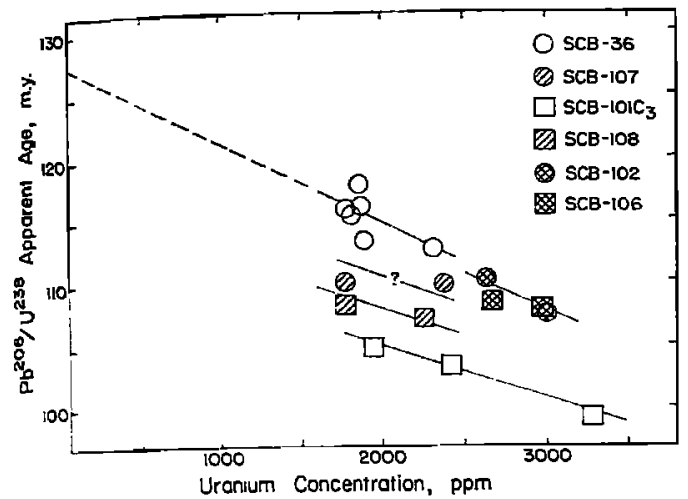

Fig. 3. $\mathrm{Pb}^{200} / \mathrm{U}^{2038}$ apparent ages of zircon fractions from each rock sample shown to be a function of their $U$ content. Circular symbols are samples of fresh rock; squares are samples of weathered rock. Dashed line indicates possible interpretation of upper limit to the true age by extrapolation to zero uranium content. Cluster of five SCB-36 points at about $1800 \mathrm{ppm}$ U represents one complete analysis and four repeat roncentration determinations. Isotopic composition of $\mathrm{Pb}$ was not obtained from the most strongly disturbed fraction of $\mathrm{SCB}-101 \mathrm{C}_{3}$.

limear and the departure of analytical points from the concordia curve is determined as much by analytical error as by the process of disturbance. By analogy with the behavior of older suites of zircon and uranothorite, we believe that $\mathrm{Pb}$ loss is the dominant mechanism of disturbance. The only likely mechanism which could seriously alter our conclusions would be preferential loss of intermediate daughter products from one of the decay chains. The simplest form of such loss would be escape of radon $\left(\mathrm{Rn}^{202}\right)$ from the $\mathrm{U}^{33 s}$ chain. It may be expected that a larger fraction of radon would escape from the uranothorites than from the zircons because of their much higher $U$ content. In such a case, the radiogenic $\mathrm{Pb}^{200} / \mathrm{Pb}^{200}$ ratios should be systematically higher for the uranothorite sumples than for the zircon samples. As will be seen below, the observed situation is opposite to this, which supports our belief that isotopic disturbance has occurred by loss of $\mathrm{Pb}$.

Accepting this conclusion, it follows that the true age of the Rubidoux granites is at least as great as the oldest $\mathrm{Pb}^{200} / \mathrm{U}^{38}$ apparent age, i.e. 116 m.y. (average of the SCB-36 R200 determinations). An independent lower limit is set by the age of a dike of pyroxene-bearing granodiorite which crosscuts both phases of the Rubidoux granites. Two fractions of zircon from this dike yielded identical isotope dilution ages of $109 \pm 1$ m.y. [Banks, 1963].

A simple linear extrapolation shown by the dashed line in Figure 3 suggests an upper limit to the true age of about $130 \mathrm{~m}$.y. Although there is no justification at present for this sort of extrapolation, the resulting interval (116130 m.y.) is compatible with other age determinations in the southern California batholith. In particular, we have obtained ages by isotope dilution on zircons from six other rock types, ranging from 106 to $119 \mathrm{~m} . \mathrm{y}$. This work is to be discussed more fully elsewhere. These ages fall within the best-determined stratigraphic interval for batholithic emplacement. Imlay [1963] describes Jurassic fossils from the preintrusive Bedford Canyon formation which place an older limit of early middle Callovian age on the batholith of southern California. Upper Cretaceous rocks resting unconformably on the batholith in the Santa Ana Mountains stipulate a younger age limit of middle to upper Turonian [Popenoe et al., 1960]. Elsewhere, in Baja California, batholithic rocks were intruded in the interval from Albian to Maestrichtian [Silver et al., 1963]. These data indicate that most of the batholith is younger than $145 \pm$ $10 \mathrm{~m} . \mathrm{y}$. but older than $85 \pm 5 \mathrm{~m} . \mathrm{y}$. (see, for example, Kulp [1961]). It seems likely from all evidence that the true age of the Rubidoux granites is close to $120 \mathrm{~m} . \mathrm{y}$.

The radiogenic $\mathrm{Pb}^{207} / \mathrm{Pb}^{200}$ ratio of each mineral fraction must correspond to an apparent age somewhere between the $\mathrm{Pb}^{200} / \mathrm{U}^{\text {mss }}$ apparent age of that fraction and the true age if the

TABLE 4. Isotopic Composition of Common Lead from Various Sources Likely to Contaminate the Radiogenic Lead Analyses

\begin{tabular}{|c|c|c|c|}
\hline & $\mathrm{Pb}^{206}$ & $\mathrm{~Pb}^{207}$ & $\mathrm{~Pb}^{208}$ \\
\hline Source of Lead & $\mathrm{Pb}^{204}$ & $\mathrm{~Pb}^{304}$ & $\mathrm{~Pb}^{204}$ \\
\hline $\begin{array}{l}\text { Borax flux } \\
\text { Ammonium citrate } \\
\text { Acid bath }\end{array}$ & $\begin{array}{l}17.83 \\
18.14 \\
18.68\end{array}$ & $\begin{array}{l}15.55 \\
15.58 \\
15.66\end{array}$ & $\begin{array}{l}37.62 \\
37.93 \\
38.22\end{array}$ \\
\hline $\begin{array}{l}\text { Mount Rubidoux } \\
\text { feldspar }\end{array}$ & 18.95 & 15.62 & 38.52 \\
\hline
\end{tabular}




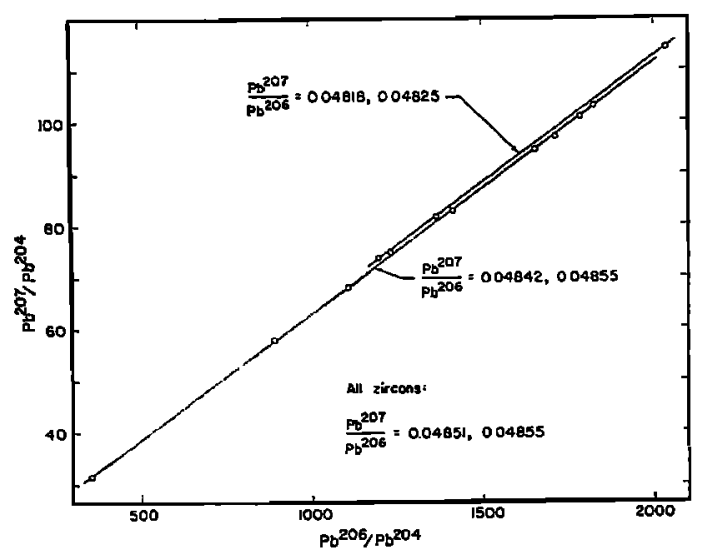

Fig. 4. Composite radiogenic $\mathrm{Pb}^{207} / \mathrm{Pb}^{200}$ ratios for zircon fractions, derived by least-squares analysis. Upper line is drawn through four samples possibly contaminated with anomalous lead. Dual figures show the result of using each coordinate in turn as the independent variable.

disturbance is caused by $\mathrm{Pb}$ loss. Moreover, more strongly disturbed samples should have slightly lower $\mathrm{Pb}^{207} / \mathrm{Pb}^{200}$ ratios than less strongly disturbed samples. The maximum possible difference between the 'proper' values of this ratio (values which would be obtained if analytical errors were zero) for the least and most disturbed samples is about $1.3 \%$, corresponding to complete loss of $\mathrm{Pb}$ from one of the uranothorite samples episodically at 87 m.y. and partial loss from the other samples at the same time. Such a situation is geologically unreasonable, and therefore we believe that the actual spread in proper values is probably considerably less.

The right-hand columns of Tables 2 and 3 show the radiogenic $\mathrm{Pb}^{200} / \mathrm{Pb}^{306}$ ratio for each mineral fraction, obtilined by using the common $\mathrm{Pb}$ correction shown at the bottom of each table. A survey was made of the isotopic composition of common $\mathrm{Pb}$ in the reagents, in the acid bath used to clean glassware, and in the feldspar of the coarse-grained Mount Rubidoux granite, and the results are given in Table 4. The maximum difference in the radiogenic $\mathrm{Pb}^{207} / \mathrm{Pb}^{200}$ ratio of any one sample caused by using these different common $\mathrm{Pb}$ corrections is less than $0.5 \%$. The range of observed radiogenic ratios is slightly over $3 \%$, which is outside the limits of error caused by an incorrect choice of common $\mathrm{Pb}$, the errors inherent in mass spectrometry, and the uncertainty in the proper values of the $\mathrm{Pb}^{207} / \mathrm{Pb}^{206}$ ratios. Another source of difficulty is the possibility of contamination of the samples with 'anomalous' $\mathrm{Pb}$. All other $\mathrm{Pb}$ analyzed in this laboratory, consisting of older radiogenic $\mathrm{Pb}$ and enriched tracer $\mathrm{Pb}$, have higher $\mathrm{Pb}^{207} / \mathrm{Pb}^{208}$ ratios than the Rubidoux samples. Very small amounts of some of these leads, especially the tracers, would measurably affect the observed radiogenic ratios. The paths by which contamination might occur are not known, although one possibility is a retention of minute quantities of $\mathrm{Pb}$ in the glassware, which until late in the study was used in common for all determinations. It is also possible that occasional zircon grains have cores of older material, although none was seen in mineral separates or grain mounts. These difficulties cannot be quantitatively evaluated, but we believe there is some consequent justification for discounting samples with the highest $\mathrm{Pb}^{207} / \mathrm{Pb}^{300}$ ratios.

To calculate $\lambda_{253}$, the simplifying approximation has been made that the spread in the proper values of the radiogenic $\mathrm{Pb}^{\mathrm{mon}} / \mathrm{Pb}^{\mathrm{mon}}$ ratios for all fractions of a given mineral species is less than the analytical uncertainty. P0ssible exceptions to this approximation would be those samples which appear to have been contaminated with anomalous $\mathrm{Pb}$. The ob-

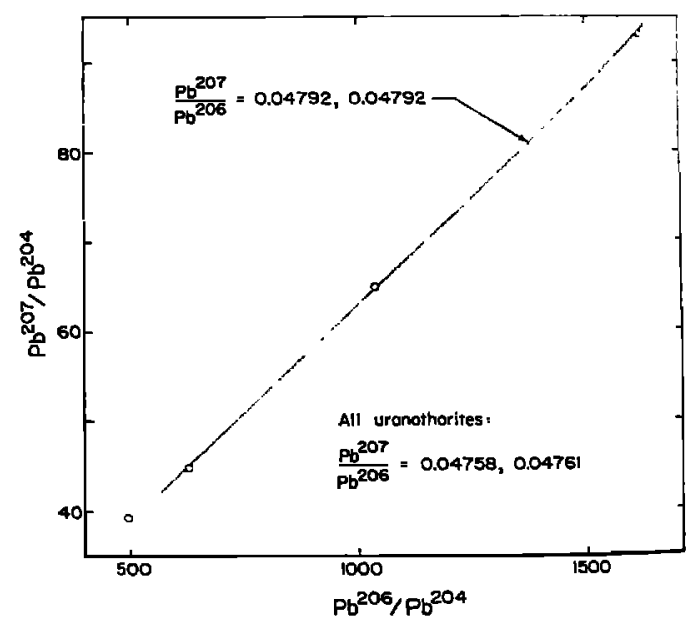

Fig. 5. Composite radiogenic $\mathrm{Pb}^{207} / \mathrm{Pb}^{200}$ ratios for uranothorite fractions, derived by least-squares analysis. Dual figures show the result of using each coordinate in turn as the independent variable. 
served $\mathrm{Pb}^{207} / \mathrm{Pb}^{204}$ ratios can then be plotted versus the observed $\mathrm{Pb}^{206} / \mathrm{Pb}^{204}$ ratios, and the slope of a straight line through the data points provides a 'best value' for the average radiogenic $\mathrm{Pb}^{\mathrm{ng}} / \mathrm{Pb}^{200}$ ratio of that mineral species. This procedure has the advantage of eliminating from consideration possible errors due to a specific choice of common $\mathrm{Pb}$ correction. Figure 4 shows such a plot for the zircon analyses. The data have been divided into two groups, one of which is slightly but consistently richer in $\mathrm{Pb}^{207}$. The four points constituting this group correspond to the four zircon fractions having the highest radiogenic $\mathrm{Pb}^{207} / \mathrm{Pb}^{206}$ ratios in Table 2. Because of their consistent departure from the rest, these four zircon fractions are interpreted to be slightly contaminated with anomalous $\mathrm{Pb}$. The straight lines in Figure 4 have been fitted by least-squares analysis to the two sets of points. The slope of the lines depends slightly on whether the $\mathrm{Pb}^{200} / \mathrm{Pb}^{204}$ ratio or the $\mathrm{Pb}^{207} / \mathrm{Pb}^{204}$ ratio is chosen as the independent variable, so that two values for each slope are given. Also indicated in Figure 4 is the average $\mathrm{Pb}^{202} / \mathrm{Pb}^{200}$ ratio for all zircon fractions. If anomalous contamination of the four previously mentioned samples has indeed occurred, there is little meaning to the slope of the line drawn through those points and it is shown chiefly to emphasize the nature of their departure.

TABLE 5. Values of $\lambda_{235}$ in Units of $10^{-10} \mathrm{yr}^{-1}$, Calculated from All Least-Squares Data Shown in Figures 4 and 5

(The calculations have been carried out by assigning probable minimum and maximum apparent ages to which the $\mathrm{Pb}^{207} / \mathrm{Pb}^{206}$ ratios should correspond. Lower and upper age limits for the zircons are 115 m.y. and 130 m.y., and for the uranothorites 105 m.y. and 125 m.y.)

\begin{tabular}{lccc}
\hline \multicolumn{1}{c}{ Mineral } & \begin{tabular}{c}
$\mathrm{Pb}^{207}$ \\
\cline { 3 - 4 }
\end{tabular} & $\begin{array}{c}\mathrm{Pb}^{206} \\
\text { Age Lower } \\
\text { Age Limit }\end{array}$ & $\begin{array}{c}\lambda_{235}, \text { Upper } \\
\text { Age Limit }\end{array}$ \\
\hline Zircon & 0.04855 & 9.810 & 9.752 \\
Zircon & 0.04851 & $\mathbf{9 . 8 0 3}$ & 9.744 \\
Zireon & 0.04842 & $\mathbf{9 . 7 8 5}$ & 9.727 \\
Zireon & 0.04825 & $\mathbf{9 . 7 5 3}$ & 9.695 \\
Zircon & 0.04818 & 9.739 & 9.682 \\
Uranothorite & 0.04792 & 9.728 & 9.652 \\
Uranothorite & 0.04761 & $\mathbf{9 . 6 6 8}$ & $\mathbf{9 . 5 9 3}$ \\
Uranothorite & 0.04758 & 9.662 & $\mathbf{9 . 5 8 7}$ \\
\hline
\end{tabular}

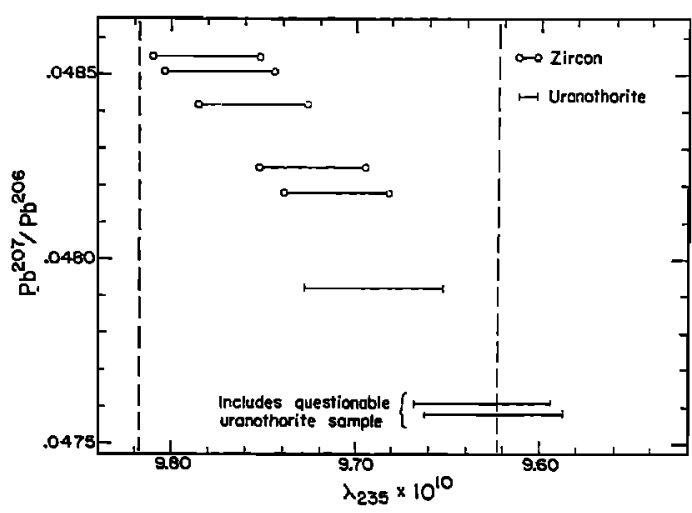

Fig. 6. Graphical summary of the calculated values of $\lambda_{235}$ listed in Table 5. Younger age limits correspond to points on the left and older age limits to points on the right. Vertical dashed lines show $1 \%$ error limits in the presently accepted value of $\lambda_{255}$.

The uranothorite data, which are statistically less reliable than the zircon data, are shown in Figure 5. A straight line has been drawn through three of the points. The remaining point has the highest radiogenic $\mathrm{Pb}^{207} / \mathrm{Pb}^{300}$ ratio in Table 3 and may, therefore, be contaminated with anomalous $\mathrm{Pb}$. It is also one of the least radiogenic of all samples and hence is susceptible to the largest analytical error. It exerts a noticeable influence on the slope of il line through all the uranothorite data.

The decay constant of $U^{235}$ is calculated from the least-squares slopes by means of equation 2 , using the values of $\lambda_{\text {sss }}$ and $\mathrm{U}^{239} / \mathrm{U}^{203}$ listed it the beginning of this paper. On the basis of the arguments presented earlier, the composite radiogenic $\mathrm{Pb}^{207} / \mathrm{Pb}^{\text {200 }}$ ratios obtained from the zircons are assumed to correspond to an apparent age greater than 115 m.y. but less than 130 m.y. The uranothorites, being generally more strongly disturbed, have been assigned limits to the $\mathrm{Pb}^{207} / \mathrm{Pb}^{200}$ apparent age of 105 ind $125 \mathrm{~m} . \mathrm{y}$.

The results of the calculation for each value of $\mathrm{Pb}^{207} / \mathrm{Pb}^{206}$ shown in Figures 4 and 5 , with the appropriate age limits, are listed in Table 5 and are summarized graphically in Figure 6. All values of $\lambda_{\text {ass }}$ so calculated fall within $1 \%$ of the presently accepted value, except where the questionable uranothorite sample has been included. Because of the anomalous nature of this sample, we believe it should be rejected from consideration. 
These calculations strongly suggest that the presently accepted decay constant of $\mathrm{U}^{2 a 5}$ cannot be as much as $2 \%$ in error, and is very likely accurate to within $1 \%$, relative to the other constants used in the calculation. The uncertainties of the method employed here, and the isotopic disturbance experienced by the samples, do not permit a more precise determination. However, if we assume that our corrections have not introduced any consistent bias, a 'best value' for $\lambda_{2 s 5}$ could be obtained from the data for the eight best zircon samples, using an assigned age of $120 \mathrm{~m} . \mathrm{y}$. This yields

$$
\lambda_{285}=9.78_{-0.10}^{+0.04} \times 10^{-10} \mathrm{yr}^{-1}
$$

The uncertainty is assigned on the basis of subjective evaluation of the many complicated sources of error and uncertainty in the entire derivation procedure. Inasmuch as this value is not significantly different from the presently accepted value, and because in our evaluation the most important sources of error are probably unidirectional toward the accepted constant, we believe the current value should continue to be used. Further investigations of this nature, including interlaboratory comparisons, may help to refine the relationship $\lambda_{250} / \lambda_{2 s s}$. At this point, however, it appears that an error in $\lambda_{25 s}$ is not adequate to resolve the geochronological discrepancies.

Acknowledgments. We express our thanks to G. Baenteli, C. R. McKinney, V. Nenow, and C. Baumann for adrice and assistance throughout the work.

This work was performed while Banks was a graduate assistant and N.S.F. Fellow at the California Institute of Technology and was supported by U. S. Atomic Energy Commission contract AT (04-3)-427, supplemented by a grant-in-aid from the Society of the Sigma $\mathrm{Xi}$ for special equipment. A.E.C. contribution CALT-427-4.

\section{REFERENCES}

Banks, P. O., Some systematics of uranium and lead distribution in relation to the petrology of The Mt. Rubidoux granites, Riverside County, California, Ph.D. thesis, California Institute of Technology, 1963.

Chow, T. J., and C. R. McKinney, Mass spectrometric determination of lead in manganese nodules, Anal. Chem., \$0, 1499-1503, 1958.

Doe, B. R., G. R. Tilton, and C. A. Hopson, Lead isotopes in feldspars from selected granitic rocks associated with regional metamorphism, J. Geophys. Res., 70, 1947-1968, 1965.
Fleming, E. H., Jr., A. Ghiorso, and B. B. Cunningham, The specific alpha-activities and half-lives of $\mathrm{U}^{294}, \mathrm{U}^{225}$, and $\mathrm{U}^{230}$, Phys. Rev., 88, 642-652, 1952.

Greene, R. E., C. A. Kienberger and A. B. Meser. vey $\mathrm{U}^{235}$ content of natural uranium, Publ $K-1201$, Carbide and Carbon Chemical Com. pany, K-25 Plant, Oak Ridge, Tenn., 1955.

Imlay, R. W., Jurassic fossils from southern California, J. Paleontol., 37, 97-107, 1963.

Kulp, J. L., Geologic time scale, Science, 133. 1105-1114, 1961.

Larsen, E. S., Jr., Batholith and associated rocks of Corona, Elsinore, and San Luis Rey quadrangles, southern California, Geol. Soc. Am. Mem. 29, 1948.

McKinney, C. R., Mass spectrometer discrimination (abstract), J. Geophys. Res., 67, 1647, 1962.

Nier, A. O., Isotopic constitution of uranium and the half-lives of the uranium isotopes, 1 , Phys. Rev., 55, 150-153, 1939a.

Nier, A. O., Isotopic constitution of radiogenic leads and the measurement of geologic time, 2, Phys. Rev., 55, 153-163, 1939 b.

Popenoe, W. P., R. W. Imlay, and M. A. Murphy, Correlation of the Cretaceous formations of the Pacific coast (United States and northwestem Mexico), Bull. Geol. Soc. Am., 71, 1491-1540, 1960.

Russell, R. D., and L. H. Ahrens, Additional regularities among discordant lead-uranium ages, Geochim. Cosmochim. Acta., 11, 213-218, 1957.

Silver, L. T., The uses of cogenetic uranium-lead isotope systems in zircons in geochronology, in Radioactive Dating, International Atomic Energy Agency, Vienna, 1963.

Silver, L. T., and S. Deutsch, Uranium-lead isotopic variations in zircons: a case study, J. Geol., $\pi 1,721-758,1963$.

Silver, L. T., F. G. Stehli, and C. R. Allen, Lower Cretaceous pre-batholithic rocks of northern Baja California, Mexico, Bull. Am. Assoc. Petrol. Geologists, 47, 2054-2059, 1963.

Tilton, G. R., Volume diffusion as a mechanism for discordant lead ages, J. Geophys. Res., 66, 2933-2946, 1960.

Wasserburg, G. J., Diffusion processes in leaduranium systems, J. Geophys. Res.y 68, 4823$4846,1963$.

Wetherill, G. W., An interpretation of the Rhodesis and Witwatersrand age patterns, Geochim. Cosmochim. Acta, 9, 290-292, 1956 a.

Wetherill, G. W., Discordant uranium-lead ages, Trans. Am. Geophys, Union, $97,320-326,1956 b$.

Wetherill, G. W., Discordant uranium-lead ages, 2, Discordant ages resulting from diffusion of lead and uranium, J. Geophys. Res., 6S, 29572966, 1963.

(Manuscript received December 11, 1965; revised May 4, 1966.) 